\title{
THE HISTORY AND OPERATION OF THE BRIGGS LAW OF MASSACHUSETTS
}

\author{
WINERED OVERHOLSRR *
}

The problem of the mental capacity of persons accused of crime is one which has for several centuries been of considerable interest to the courts. Apparently prior to the middle of the eighteenth century, however, no great difficulty was experienced by the court in obtaining reliable evidence on this question-since at that time the experts were called in by the court as amici curiae. During the past two hundred years, however, the position of the experts has tended to develop into that of partisans, ${ }^{1}$ and criticism has been widespread and caustic on the part not only of judges and lawyers but of the general public. ${ }^{2}$ By reason of the sensational nature of the crime charged in some cases where insanity is pleaded as a defense, undue attention has been focused by the public upon the rôle of the psychiatrist as an expert witness in criminal trials, despite the well recognized abuses of other types of expert testimony, criminal and civil alike. If criticism has been rampant, however, it cannot truthfully be said that no attempts have been made to improve the situation. Some of these attempts have partaken of the nature of action by professional societies, but the ones which concern us particularly are those which have been enacted into legislation.

Of the types of legislative cures proposed, the most common has been that conferring upon the court the right or the duty, in certain specified cases, of appointing neutral experts. Certain practical objections have been made to this method,notably the fact that the judge may not be properly qualified to pass on the ability of the expert; the fact that politics may become a consideration in the appointment of

- A.B., I912, Harvard University; M.B., I915, M.D., 1916, Boston University School of Medicine. Commissioner, Massachusetts Department of Mental Diseases. Lecturer, Boston University School of Law. On Staff of Westborough, Gardner and Medfield State Hospitals (Mass.) 1917-1924 (leave of absence rgr8-rgrg for service in Neuro-Psychiatric Section, Medical Corps, United States Army). Assistant to Commissioner of Mental Diseases, 1924-1925; Director, Division for the Examination of Prisoners, 19251930; Assistant Commissioner, r930-I934. Formerly Professor of Psychiatry, Boston University School of Medicine; President, Massachusetts Psychiatric Society, I933-1934; Councilor, Amcrican Psychiatric Association, since 1934 .

${ }_{4}$ WIGMORE, Evidence (2d ed. 1923) \$rg17, pp. roo-109. For a consideration of the historical development of rules governing the expert witness in Anglo-American law, see Rosenthal, supra, at p. 403.

"Hardly any weight is to be given to the evidence of what are called scientific witnesses." Tracy Peerage Case, ro Cl. \& F. 154 (1839). "Expert testimony is regarded by the law as the weakest character of testimony." Ky. Traction Co. v. Humphrey, 168 Ky. 611, I82 S. W. 854 (I916). 
the expert; ${ }^{3}$ and that in any event the initiative must come from the defendant by the introduction of a plea of insanity. One of the early attempts (Igro) was that of the State of Washington, which proposed to remove consideration of mental condition from the trial, leaving the disposition to be determined after the innocence or guilt of the commission of the act itself had been passed upon. This legislation was declared unconstitutional by the Supreme Court of that State. ${ }^{4}$ More recently (rg28) the State of Louisiana proposed to make the findings of a specially constituted commission final; but this act too was declared unconstitutional, on the ground that the accused had the right to have the defense of insanity, like any other defense, considered by a jury. ${ }^{5}$ The State of California in $1927^{6}$ complicated matters by setting up a double trial-the first on the question of guilt or innocence of the act, and the second on the question of insanity at the time of the act; this to be applicable in cases where a special plea of insanity was introduced. This procedure has been rather severely criticised by judges and legal writers in its native state, and certainly is not a fundamental cure, even though it was modified in 1929 by provision for the court appointment of experts. ${ }^{7}$ The State of Mississippi (r928) abolished entirely the defense of insanity, but this law was declared unconstitutional. ${ }^{8}$ The State. of Colorado $^{\theta}$ requires the commitment to a mental hospital of any defendant who pleads not guilty by reason of insanity-such commitment to be for an observation period. This provision does well as far as it goes, but again it is dependent upon the initiation of a plea of insanity. There is no assurance that a case of mental disorder may not pass unrecognized, with a resulting unfairness to the defendant, and, on the other hand, there is no discouragement to the introduction of a plea of insanity which may be well known to the attorney to be specious. The fact that in 1934 a total of only $3^{\mathrm{I}}$ cases were referred by all the courts of the Commonwealth of Massachusetts for mental examination under an optional statute ${ }^{10}$ serves to suggest that the selection of suitable cases by the courts can hardly be counted upon!

An editorial in the Boston Post of February 28, 1929, illustrated well the extremes to which favoritism and nepotism may go. According to the editorial, relatives of the county judges of Kings County, New York City, received $\$ 140,000$ in fees for services on lunacy commissions during I928. One of these relatives was an ophthalmologist, one an obstetrician, and one a dealer in pianos!

'State v. Strasburg, 60 Wash. 106, r 10 Pac. 1020 (1910). See Rood, Statutory Abolition of the Defense of Insanity in Criminal Cases (1910) 9 Mrch. L. Rev. 126.

'State v. Lange, I68 La. 958, I23 So. 639 (1929).

- Cal. Acts 1927, c. 677. See Shepherd, The Plea of Insanity Under the 1927 Amendment to the California Penal Code (I929) 3 So. Carif. L. Rev. I.

${ }^{2}$ Car. Penal Code (Deering, r931) \$1027.

- Sinclair v. State, 16I Miss. 142, 132 So. 58I (1931).

- Colo. Acts 1927 , c. 90. For a discussion of the operation of the Colorado law and analogous statutes, see Weihofen, An Alernative to the Battle of Experts: Hospital Examination of Criminal Defendants Before Trial, supra, pp. 422-432.

${ }^{10}$ Mass. Awn. Lsws (Michie, I933) c. 123, 599. Unlike the Briggs Law, quoted infra, p. 440, under which the reporting of cases for examination is mandatory but which is limited to capital cases and to persons under indictment who bad previously been indicted more than once or convicted of felony once before, this provision authorizes the presiding judge, "in his discretion," to request examination "in order to determine the mental condition of any person coming before any court of the commonwealth." (Italics added.) The smallness of the number of cases in which this power has been exercised is all the more 
There is a remarkable unanimity of legal writers to the effect that the Massachusetts procedure relative to persons accused of crime is by far the most advanced step which has yet been taken in meeting the criticism leveled at the prevalent practice of the use of experts in criminal trials, and for this reason it seems proper to consider it in some detail in connection with a symposium on the general problems relating to expert testimony. ${ }^{11}$ The credit for the conception and the enactment of this law belongs to Doctor L. Vernon Briggs of Boston, a prominent physician who has long been active in initiating and encouraging psychiatric progress in Massachusetts. It was first proposed by Dr. Briggs in I92I in his volume entitled, The Manner of Man That Kills, ${ }^{12}$ as being a form of law necessary to any scheme which purports to be fair to the defendant accused of serious crime and as a practical means of correcting the abuses of psychiatric expert testimony in criminal trials. In I921 Governor Channing $\mathrm{H}$. Cox in his inaugural address made certain recommendations regarding the treatment of offenders, which were referred to the Committee on Public Health of the Legislature. Dr. Briggs urged upon this Committee, during its consideration of the Governor's message, the reporting of a law to provide for an investigation by the Department of Mental Diseases as to the mental condition of certain persons held for trial. Dr. Briggs had already consulted with a number of prominent attorneys, including the President of the Massachusetts Bar Association, and with the Commissioner of Probation, who spoke in behalf of the bill. It is somewhat interesting to note that the original misgivings relative to the constitutionality of the bill came from physicians rather than from the lawyers. The principal opposition came from the clerk of one of the larger courts who organized a lobby against the bill-apparently in the fear that it would cause too much additional work!

In spite of this opposition the bill was enacted as Chapter 415, Acts of Ig2I, providing, essentially, that a person indicted for a capital offense or any person known to have previously been indicted more than once, or previously convicted of a felony, should be examined by the Department of Mental Diseases, "with a view to determine his mental condition and the existence of any mental disease or defect which would affect his criminal responsibility." Provision was also made that this report should be accessible to the court, the district attorney and the attorney for the accused, and should be admissible as evidence on the mental condition of the accused. No fee was provided for this examination, and it seems probable that it was hoped by the opponents of the bill that this omission would be fatal to the proper operation of the

noteworthy in the light of the volume of cases to which it extends, since it is applicable equally to all civil as well as to all criminal cases.

"11 For a detailed.study of the Briggs Law, with full bibliography, see Overholser, The Briggs Law of Massachusetts: A Review and an Appraisal (1934-35) $25 \mathrm{~J}$. CRIM. L. \& Crimin. 859-883. The author is greatly indebted to Dr. L. Vernon Briggs for much of the original information embodied in the present paper. Doctor Briggs opened his files to the author, and communicated much of the historical data here presented. See also Briggs, Conditions and Events Leading to the Passage of the Massachusetts Law Commanly Called the "Briggs Law," I2 Bulletin, Mass. Dept. Mental. Diseases, Nos. 1 \& 2, pp. $2-5$.

13 At pp. I6-I7. 
law. Nothing daunted, however, Dr. Briggs secured from the practicing psychiatrists of Boston an agreement that they would make the examinations without remuneration until such time as a fee could be provided. We thus find illustrated at the outset the necessity of individual initiative and the coöperation of interested parties as essential to the proper functioning of a law. It should be said at this point that the continued interest and active support by Dr. Briggs have done much to bring about the continuing and increasing effectiveness of the Briggs Law.

In I923, upon the recommendation of the Commissioner of Mental Diseases, Dr. George $M$. Kline, the statute was amended ${ }^{13}$ to provide a fee-this fee being four dollars for each of the examining physicians plus a mileage allowance of twenty cents per mile one way. It seems safe to say that this fee, although to a small extent a recognition of the monetary value of the services rendered, is hardly large enough to be considered a basis for venality on the part of the examiners! In his annual reports for $1923^{14}$ and $1924,{ }^{15}$ the Attorney General recommended that the law be further amended to strike out the provision that the report should be admissible as evidence on the ground that under the law the Commonwealth could not constitutionally offer such a report as evidence, although the defendant might, such an arrangement being manifestly unfair. On the basis of this recommendation of the Attorney General, the Legislature in 1925 struck out this provision for admissibility and also provided a penalty for wilful non-compliance by clerks of court. ${ }^{16}$ In spite of the penalty, and in spite of the fact that some increase in the number of cases reported was being noted, it was obvious from the figures that many defendants were not being reported, even though their previous records undoubtedly rendered them eligible for examination. The Commonwealth of Massachusetts was fortunate in having already existing a central bureau of records, centralized in the Board of Probation, a probation officer in every court, and a statutory provision that before a defendant was admitted to bail by the court the probation officer should ascertain his previous record.17 Accordingly, on the petition of Doctor Briggs and Senator Samuel $\mathrm{H}$. Wragg, the Legislature in 1927 provided that it should be part of the duty of the probation officer if he had in his possession information which indicated that a defendant came within the provisions of the Briggs Law, to report that fact to the clerk who should thereupon act upon this information. ${ }^{18}$ An immediate and startling jump in the number of cases reported was noted. This amendment probably has had more to do with the efficient reporting of cases under the Briggs.Law than any other. In 1929 on the petition of the Commissioner of Mental Diseases, Dr. Kline, the act was further amended ${ }^{19}$ to provide that the report under the Briggs Law should be available to the probation officer of the court. This seemed only logical in view of the fact that under the Massachusetts law the probation officer is

\footnotetext{
Mass. Acts I923, c. 33 I.

"At p. $\mathrm{II}$.

${ }^{10}$ Mass. Acts 1925 , c. 169 .

${ }^{18}$ Mass. Acts 1927 , c. 59 .
}

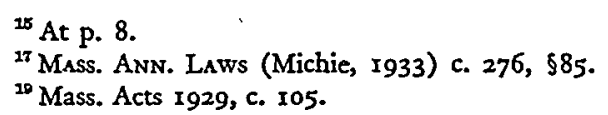


the official of the court who is charged with the duty of advising the judge as to pertinent facts to be considered in imposing sentence. No opposition to any of these proposed amendments was encountered, and it appeared that the general public, the courts and the legislature were content to abide by the judgment of the author of the law and of the Department of Mental Diseases in details of wording and in minor substantive changes.

One further provision seemed desirable. The original law, as we have seen, provided for the examination of persons indicted for a capital offense,-namely, first degree murder or accessory before the fact of first degree murder-as well as of those previously indicted more than once or convicted of a felony who were again before the court on an indictment or bound over for trial. Several instances had arisen in which persons with a previously clear record had been indicted for murder in the second degree, for rape, for robbery while armed, or for some other offense for which life imprisonment might be imposed but which were not capital offenses. In some of these cases there were psychiatric implications, and it seemed only fair that a defendant should be given the benefit of a mental examination before standing trial on a charge which might result in a life sentence. Accordingly, in $1930^{20}$ and again in 193r, ${ }^{21}$ on the recommendation of the Commissioner of Mental Diseases, Dr. Kline, the Legislature was asked to amend the Briggs Law by striking out the words "a capital offense" and inserting in place thereof the words "any offense punishable by death or imprisonment for life." On both occasions the proposed amendment failed of passage. The Judiciary Committee which heard the bill (the previous amendments had been heard by the Committee on Public Health, except the one in I925 relative to the admissibility of the report as evidence) seemed somewhat skeptical of the proposal to increase the scope of the law, even though they were assured that the number of defendants coming under the provision would be relatively small. The failure of passage was due to legislative inertia rather than to active opposition -this, of course, being a fate which frequently overtakes new or progressive proposals.

Having thus reviewed at some length the legislative history of the Briggs Law, we may proceed to study the provisions of the law as it now stands. The statute ${ }^{22}$ reads as follows:

"Whenever a person is indicted by a grand jury for a capital offense or whenever a person, who is known to have been indicted for any other offense more than once or to have been previously convicted of a felony, is indicted by a grand jury or bound over for trial in the superior court, the clerk of the court in which the indictment is returned, or the clerk of the district court or the trial justice, as the case may be, shall give notice to the department of mental diseases, and the department shall cause such person to be examined, with a view to determine his mental condition and the existence of any mental disease or defect which would affect his criminal responsibility. Whenever the probation officer of such court has in his possession or whenever the inquiry which he is required to

${ }^{20}$ Mass. H. B. 38 .

Mass. Ann. Laws (Michie, I933) c. I23, \$100-A. 
make by section eighty-five of chapter two hundred and seventy-six discloses facts which if known to the clerk would require notice as aforesaid, such probation officer shall forthwith communicate the same to the clerk who shall thereupon give such notice unless already given. The department shall file a report of its investigation with the clerk of the court in which the trial is to be held and the report shall be accessible to the court, the probation officer thereof, the district attorney and to the attorney for the accused. In the event of failure by the clerk of a district court or the trial justice to give notice to the department as aforesaid the same shall be given by the clerk of the superior court after entry of the case in said court. Upon giving the notice required by this section the clerk of a court or the trial justice shall so certify on the papers. The physician making such examination shall, upon certification by the department, receive the same fees and traveling expenses as provided in section seventy-three for the examination of persons committed to institutions and such fees and expenses shall be paid in the same manner as provided in section seventy-four for the payment of commitment expenses. Any clerk of court or trial justice who wilfully neglects to perform any duty imposed upon him by this section shall be punished by a fine of not more than fifty dollars."

A study of the wording of the law indicates the three essential features which, at least in such combination, are still unique, in spite of the fact that the law has been in successful operation for fourteen years. In the first place, the reference of the case is automatic, that is, it does not depend upon the introduction by the defendant of a plea of insanity or upon the alleged "recognition" by a jail official, attorney, judge, or some other non-psychiatrist, of mental disorder. Within the legal limits of the classes designated every person accused of crime is examinable in advance of trial, whether or not mental disease is suspected. The legal categories enunciated may safely be assumed to include the more "serious" offenders, if, indeed, any such distinction is to be drawn between classes of offenders. In a considerable number of instances prisoners have been examined who have had no counsel and in whose cases mental disease had not been suspected, even though it was clearly demonstrated by the examination. Secondly, the examination is made by impartial examiners. The request comes from the clerk of the court, the report is made to the clerk, and is accessible to the counsel for the defense as well as to the district attorney. The examiners are under no obligation to either side, and are asked merely to make a thorough and conscientious report. Third, the selection of the examiners is made by a professional, non-political department in the administrative branch of government, namely, the Department of Mental Diseases. Massachusetts is fortunate in that its Department of Mental Diseases has traditionally been free from politics and that, furthermore, the Department (consisting of a commissioner and four associate commissioners) is made up of a majority of qualified psychiatrists. Presumably the qualifications of psychiatrists may better be passed upon by other psychiatrists than by judges or the court officials, a fact which has been recognized by judges themselves in commenting upon the selection of experts.

A synoptic table indicating the development of the use of the law is presented below. I am happy at this point to express my indebtedness to Professor S. Sheldon 
Glueck of the Harvard Law School, whose review of the statistics published in 1926 has been extremely helpful to the writer as the basis for his subsequent reports on the operation of the law:

\begin{tabular}{|c|c|c|c|c|c|c|c|c|}
\hline $\begin{array}{c}\text { Year } \\
\text { (Ending } \\
\text { Oct. 15) }\end{array}$ & $\begin{array}{c}\text { Cases } \\
\text { Reported }\end{array}$ & $\begin{array}{c}\text { Cases } \\
\text { Examined }\end{array}$ & $\mid \begin{array}{c}\text { Percent } \\
\text { Not } \\
\text { Examined }\end{array}$ & Insane & $\begin{array}{l}\text { Observa- } \\
\text { tion } \\
\text { Advised }\end{array}$ & $\begin{array}{l}\text { Mentally } \\
\text { Defective }\end{array}$ & $\begin{array}{l}\text { Other } \\
\text { Mental } \\
\text { Abnor- } \\
\text { malities }\end{array}$ & $\begin{array}{l}\text { Percentage } \\
\text { Reported } \\
\text { Abnormal }\end{array}$ \\
\hline $\begin{array}{c}1921-1926 . \\
(5 \mathrm{yrs} .) \\
1927 \ldots \ldots \\
1928 \ldots \ldots \\
1929 \ldots \ldots \\
1930 \ldots \ldots \\
1931 \ldots \ldots \\
1932 \ldots \ldots \\
1933 \ldots \ldots \\
1934 \ldots \ldots\end{array}$ & $\begin{array}{c}367 \\
\text { (av.73.2) } \\
138 \\
239 \\
370 \\
654 \\
766 \\
909 \\
818 \\
911\end{array}$ & $\begin{array}{c}295 \\
\text { (av. 59) } \\
87 \\
179 \\
283 \\
521 \\
703 \\
817 \\
725 \\
782\end{array}$ & $\begin{array}{r}19.6 \\
37 . \\
25.1 \\
23.5 \\
20.3 \\
8.2 \\
10.1 \\
11.3 \\
14.1\end{array}$ & $\begin{array}{r}26 \\
5 \\
6 \\
3 \\
4 \\
8 \\
6 \\
3 \\
5\end{array}$ & $\begin{array}{r}7 \\
1 \\
6 \\
16 \\
23 \\
21 \\
26 \\
23 \\
20\end{array}$ & $\begin{array}{r}25 \\
9 \\
21 \\
27 \\
44 \\
87 \\
68 \\
55 \\
52\end{array}$ & $\begin{array}{r}11 \\
1 \\
13 \\
11 \\
10 \\
10 \\
19 \\
15 \\
6\end{array}$ & $\begin{array}{l}25.4 \\
18.3 \\
25.7 \\
20.1 \\
15.7 \\
17.9 \\
14.5 \\
13.2 \\
10.6\end{array}$ \\
\hline Total. . & 5,172 & 4,392 & $\ldots$ & 66 & 143 & 388 & 96 & $\ldots$ \\
\hline
\end{tabular}

Not examined, 780 , or $15.1 \%$ of all cases reported.

Total, all classes, 693 , or $15.8 \%$ of all cases examined.

Several facts of interest are noted on the perusal of this first table. First of all is the startling, annual increase of the cases reported-beginning with a yearly average of 73.2 in the period $1921-1926$ and reaching a peak in 1932 of 909 , an increase of $1 \times 40$ per cent! It will be noted that this increase began in the year 1927, at which time the previously described amendment relative to reports by probation officers was enacted. The explanation of the slight drop in the year 1933 is not entirely clear, although it is worth noting that a slight fall in the total number of indictments. returned in the entire Commonwealth was noted also in that year, as against the preceding year. It will likewise be noted that the number of defendants reported who were not examined has fallen rather markedly. During the past four years it has apparently been a definite policy of the justices of the Superior Court to postpone disposition of cases known to come under the Briggs Law until an examination can be completed. The policy appears to be entirely consistent with the intent of the law, even though in the Vallarelli case ${ }^{23}$ it was held that non-compliance with the statute does not invalidate the trial. Most of the defendants not examined were on bail, and it seems quite likely that a certain proportion will always be missed on this account, particularly in view of the fact that the court probably has no right to compel such examination. ${ }^{24}$ It should be understood that not all defendants on bail are missed; indeed, a considerable number report for examination when requested to do so. Another point of interest is the fact that the number of defendants reported to be abnormal mentally is not so large as has been apprehended by many illinformed persons. Not uncommonly the charge is heard that psychiatrists, if given a

${ }^{23}$ Commonwealth v. Vallarelli, 273 Mass. 240, I73 N. E. 582 (1930).

24 This point has not been decided. The court at least has no power to order a physical examination. See Stack v. N. Y., N. H. \& H. R. R. Co., 177 Mass. 155, 58 N. E. 686 (1900). 
free hand, would find all defendants insane. The most effective rebuttal of this charge is that over a period of fourteen years, during which the psychiatrists have had a completely free hand, only 15.8 per cent of all cases examined have been reported to be either demonstrably abnormal mentally or in such mental condition that observation in a mental hospital seemed advisable.

A brief discussion of the facilities available for the care of mentally abnormal defendants in Massachusetts may be in order at this point. The court may commit a defendant as insane or for a period of observation without a jury trial and, indeed, even without medical evidence. ${ }^{25}$ The procedure is so simple that there would seem to be no excuse for the court's not committing for observation a defendant concerning whose sanity doubt has arisen. It is a general rule that all defendants reported to be insane are committed to a mental hospital promptly, and that the most of those for whom observation is advised are so committed. In some of the latter cases the report may have been received too late, or it may be that sufficiently convincing reasons for observation commitment were not set forth by the examiners. The following table indicates the dispositions of this group during the four years from October 15, 1931 to October 15, 1934, inclusive:

\begin{tabular}{|c|c|c|c|}
\hline & $\begin{array}{l}\text { Commitment for } \\
\text { Observation Recommended }\end{array}$ & Committed & $\begin{array}{c}\text { Per Cent } \\
\text { Committed }\end{array}$ \\
\hline I93I & $\ldots \ldots \quad 2 \pi$ & 13 & 62.8 \\
\hline 1932 & $\ldots \ldots$ & I6 & $6 \mathrm{r} .5$ \\
\hline 1933 & $\ldots \ldots$ & 16 & 69.6 \\
\hline$x 934$ & $\ldots \ldots \ldots 20$ & $I_{4}$ & 70.0 \\
\hline
\end{tabular}

A defendant acquitted of homicide by reason of insanity must be committed to a mental hospital for a term of his natural life, and may be released by the Governor and Council if, upon investigation by the Department of Mental Diseases, they are satis. fied that the prisoner may be released "without danger to others." Massachusetts is one of the two states (New York being the other) which has a defective delinquent law providing for the indeterminate commitment to a special type of institution of delinquents found to be mentally defective. ${ }^{27}$ Unfortunately the facilities are much overcrowded, and the courts have not employed this law very widely as a result of the inadequacy of facilities.

In the administration of the law the coöperation of the various groups of court officials and of the bar generally has been most gratifying. The judges, as has already been said, although somewhat hesitant at the outset, have particularly for the past four or five years been most coöperative in delaying disposition until the report can be received and in using all the means at their disposition to induce the defendant to undergo the examination. The defense attorneys have likewise been coöperative, and in many instances in which the defendant has declined to be interviewed have persuaded him that he should undergo the examination. The number of refusals

$\approx$ Mass. ANn. Laws (Michic, I933) c. I23, §roo.

Id. §rox.

${ }^{n} I d .5 \$ 113-124$. 
has been gratifyingly low. The district attorneys have shown an almost unanimous disposition to abide by the results of the examination, and in those instances in which a contest arises have tended to depend entirely upon the Department's examiners as their experts. If the report is to the effect that the defendant should be sent to a mental hospital, the motion for commitment is usually made by the district attorney.

An excellent example of the manner in which district attorneys, defense counsel, and experts coöperate under the Briggs Law occurred while this paper was in process of preparation (September 1935). The defendant, a former State Hospiral patient, had shot and killed his wife under the influence of his delusions regarding her conduct. Examined under the Briggs Law, he was reported to be "insane." He was brought into the Superior Court in Worcester County and found "not guilty by reason of insanity" in a directed verdict after the district attorney had presented the evidence of the offense and that of the psychiatrists appointed by the Department. The proceedings took only a few minutes; there were no prolonged cross-examinations, no array of partisan witnesses replying to confusing hypothetical questions, no opportunity for journalistic criticism of "hired experts"; finally, the expense was minimal. This feature of expense alone would justify the Massachusetts procedure. Many costly trials (averaging at least $\$ 500$ a day) have been avoided by the fact that the district attorney and counsel for the defense have been reliably informed in advance in cases in which the defendant was of unsound mind, and could agree on a suitable disposition. In any year the already low cost of the administration of the law has probably been saved several times over in this manner.

In general the defense attorneys as well have been inclined to abide by the result, although there have been a very few instances in which they have felt it incumbent upon them to attempt to contest the finding of sanity. The number of "battles of experts" has been extremely small, and in almost every instance if, indeed, not in all, the report of the Department has been accepted by the jury. In the fourteen years since the passage of the law, only one flagrant example of the introduction of a battery of experts has been observed, and that as recently as 1934. A considerable number of psychiatrists were imported by the defense at the expense of the Commonwealth, but failed to overturn the report of the Department's examiners. Apropos of this case, the Boston Herald commented editorially (June 6, 1935) as follows: “. . . In view of the conspicuously unsuccessful attack on the Briggs Law, Massachusetts courtrooms will probably be spared many years another scene like that in Dedham." Finally, the clerks and probation officers have been extremely helpful, and in fact the clerk of court who led the opposition to the law in the beginning told the writer, shortly before his death, that since observing its functioning he had come to consider the statute a valuable one.

It was, of course, inevitable that so novel a provision affecting criminal procedure should be brought to the attention of the Supreme Judicial Court of the Commonwealth for interpretation, and as a matter of fact several points have been decided as 
to the rights of the defendants and as to the duties of the Department, as well as to the general purpose of the Briggs Law. In deciding the first case appealed (in I926) the Supreme Judicial Court commented as follows ${ }^{28}$

"The examination is required in order that no person so indicted may be put upon his trial unless his mental condition is thereby determined to be such as to render him responsible to trial and punishment for the crime charged against him, and that he has no mental disease or defect which interferes with such criminal responsibility. It is the duty imposed by the statute upon these doctors and others similarly assigned by the Department of Mental Diseases to say what is the mental condition of an accused and whether he has any mental disease or defect affecting his criminal responsibility. . . It is a necessary deduction from all the circumstances that the defendant was put upon trial on the indictment because the report of the Department of Mental Diseases upheld his criminal responsibility. He would not have been brought to trial without evidence of his mental condition if that report had not been to the effect that he was of sufficient mental power to be criminally liable for his act and was not insane. ... Doubtless the judge knew of this report at the trial. ... He was justified in considering it in connection with the motion for a new trial in the circumstances here disclosed. . . The judge had a right to examine the cause suggested in the motion for a new trial in the light of the contents of this report, in order to aid him in ascertaining whether justice required that there be a new trial."

In another part of the same decision the impartial nature of the report was emphasized as follows:

"It is a matter of general knowledge that there are in the service of the Commonwealth under this department persons eminent for special scientific knowledge as to mental diseases. The examination under the statute, therefore, may fairly be assumed to have been made by competent persons, free from any disposition or bias and under every inducement to be impartial and to seek and ascertain the truth."

Judicial notice, then, is taken of the competence and impartiality of the examiners, and it is clearly indicated that the district attorney is not expected to bring to trial a defendant who is not pronounced to be sane and responsible. The figures already cited indicate that the district attorneys have of late, at least, followed the general lines laid down above. The expectation is further expressed that the trial judge was guided by the report.

In other cases coming before the same court it has been held ( $x$ ) that noncompliance with the provisions of the Briggs Law does not invalidate the trial as a matter of law; ${ }^{28}$ (2) that having been examined by impartial experts under the Briggs Law the defendant is not entitled as of right to a further examination at the public expense; ${ }^{30}$ and (3) that the examination does not compel the defendant to give evidence against himself in violation of his constitutional rights. ${ }^{31}$ No cases

${ }^{28}$ Commonwealth v. Devereaux, 257 Mass. 39 I, 152 N. E. 380 (1926).

"Commonwealth v. Vallarelli, supra note 23; Commonwealth v. Soaris, 275 Mass. 291, I75 N. E. $49 \mathrm{r}$ (I93I).

${ }^{\circ}$ Commonwealth v. Belenski, 276 Mass. 35, I76 N. E. 50 r (193I).

a Commonwealth v. Millen et al., 195 N. E. 541 (Mass. 1935). 
involving the Briggs Law have been so far considered in the federal courts. The constitutionality of the law has never been directly passed upon, but there seems to be no good reason to question it.

The query may very properly be made, "why is it that after fourteen years of successful operation of an extremely significant and progressive statute no other state has yet enacted similar legislation?" It would, of course, be erroneous to assume that no interest has been shown in the Briggs Law in other states, and it seems likely that this law has served as at least a suggestion or an inspiration to certain states in enacting laws designed to improve the status of expert testimony. Bills following closely the wording of the Briggs Law have in recent years been introduced both in New York and in Pennsylvania, but have not been enacted. Influential groups in certain other states, such as Kansas and New Hampshire, have gone on record as endorsing the principle of the law, but as yet their endorsement has not been translated into legislative action. A wealth of editorial newspaper comment, from Boston to Los Angeles, has been accumulated, and many articles in legal journals and treatises have praised the principle of the Briggs Law in such terms as "the most progressive legislation on the insanity defense," and "one of the greatest steps in the introduction of medical thought into the law."32 In I930, also, the Sub-Committee on the Medical Aspects of Crime of the National Crime Commission strongly urged the adoption of the Briggs Law by other States. A significant fact relative to the possible adoption of the Briggs Law principle in other states is the inclusion by the Committee on Medico-Legal Problems of the Section of Criminal Law of the American Bar Association in its model expert testimony statute of Section 8, which is an almost exact copy of the Briggs Law of Massachusetts. ${ }^{33}$ The endorsement of this Committee should certainly go far toward securing legislative approval of the principle in other states. It should perhaps be borne in mind that not all states have a situation closely comparable to that of Massachusetts,-either in the field of the courts or in the field of the psychiatric service available to the state. This feature, among others, was discussed by Judge James T. Brand in the Oregon Law Review in 1930,34 -the comment being made that Massachusetts is of insignificant area, of dense population, and of great wealth, as contrasted with Oregon, so that the unit cost of the administration of a similar law would be much greater in Oregon than in Massachusetts. The area of Oregon, for example, is approximately twelve times that of Massachusetts, whereas the population is less than one-fourth that of the latter state. Judge Brand might have added that there are only two state hospitals in the entire State of Oregon, as against sixteen in Massachusetts-so that it can readily be agreed that the situations are not comparable. It is evident that for the

\footnotetext{
* See, for a general discussion, Weihofen, Insanity as a Defense in Criminal Law (1933) 401-407; Glueck, Mental Disorder and the Criminal Law (rg23) 55-56, 58-72, 474-476.

${ }^{2}$ See Report of Committee (July, 1935) 26 J. CRIM. L. \& Crimin. 290; see also Wigmore, Evidence .(2d. ed. Supp. 1934) \$563, p. 284 .

* Brand, The Insanity Defense (I930) g ORE. L. REV. 309.
} 
proper functioning of a statute like the Briggs Law there must first of all be available competent psychiatrists in adequate numbers, and that the state hospital service would normally be expected to furnish at least the nucleus of the psychiatrists required for the operation of a law of this type. There are certain other prerequisites as well which might be enumerated as follows: a well developed central organization of the state hospitals, operated on an efficiency rather than a political basis and possessing the confidence of the public and of the courts; the existence of a central record system for the courts, so that the previous record of a defendant may readily be ascertained; still another consideration, more intangible but perhaps more important, would be a widespread public interest in the welfare of the mentally ill, and a readiness of the courts and prosecutors to take an interest in the proper disposition of those defendants who are found to be abnormal mentally. Of equal importance would be the existence of an individual, or of a group inspired by an individual, who would take the initiative not only in securing the enactment of the law, but in stimulating and encouraging its effective administration. Massachusetts is extremely fortunate in having all of these. However, not all of the prerequisites, at least, can be said to be lacking elsewhere, and it seems inevitable that the Briggs Law should continue to be an inspiration to other states to enact legislation at least modeled upon it if not identical with it. The scheme in general is adaptable to other states, although certain modifications would have to be made in some instances, dependent upon the local administrative organization. Experience has shown that no law is self-enacting or self-administering, and if the history of any statute is closely studied, the imprint of a personality can almost always be found-as the raison d'etre of the law and of its efficiency. The Briggs Law was the result of much thought, effort and initiative on the part of its author. Massachusetts may properly consider itself fortunate in having led the way to a closer union of psychiatry and the criminal law under the banner of the statute which has just been described. 